postmodernism made, it seems to me that such principles do inform the editors' approach.) The contributions largely live up to the claims of local analysis, difference and complexity and make accessible reading (often aided by the integration of the writer's reflexivity on the issue). The editors' strategy of organizing the book into three parts - stories, categories and contexts - seems consistent with their wish to challenge more conventional categorizations, although for me it did not contribute anything to the individual chapters.

What about the editors' claim to address practice, as well as discourse? Postmodern feminism has been criticized for potentially undermining the unity of purpose of feminist politics through its emphasis on the local, the diverse, and the multiple and contradictory workings of power. Significantly, therefore, there is no sign of these undermining its political awareness or its political contribution. On the contrary, I found it helpful that the book consistently avoids totalizing accounts of harassment. An edited collection such as this - often regarded with suspicion by publishers because of its potential lack of coherence - works well as a vehicle for such an approach, as long as the diversity of contributions is given sufficient structure by a coherent editorial vision. Understandably, the editorial vision is most apparent in the introductory chapter (written by Brant and Too), but none the less, at its best, this book provides a good model of postmodern political writing within an academic feminist tradition.

Wendy Hollway

\title{
Medicine and Nursing. Professions in a Changing Health Service
}

\section{Sylvia Walby, June Greenwell, Lesley Mackay and Keith Soothill}

Sage Publications: London, 1994

ISBN 080398742 O, f11.95 Pbk, ISBN 0803987412 Hbk

This book attempts to bring together important strands in the sociology of work, the sociology of the professions, gender issues, and the sociology of health, in order to examine recent social policy decisions and changes in the British National Health Service. The most important feature of the text is its thorough and consistent review of the literature which brings together all the different strands of thinking. We feel the strength of the book also turns out to be the cause of some of its weaker points. In trying to deal with so much material, the authors at times lose track 
of their argument. We feel this particularly to be the case when they are relating their empirical work (based on 262 interviews with doctors and nurses working on acute hospital wards) to the main theories which they present. The main themes are the impact of Fordism and postFordism on certain groups of workers in the health service, the perceptions of doctors and nurses in relation to the shifting boundaries between their professions, the strategies of professionalization in nursing including primary nursing and Project 2000, and gender issues within the NHS, which is the largest employer in the UK.

The book is well structured with useful signposts and excellent summaries. After a general introduction which sets the scene with an account of Fordism and post-Fordist styles of management, and a discussion of some of the issues of interest concerning inter-professional work in a context of professionalization, there are individual chapters on specific issues. Chapter 2 demonstrates that a division between care and treatment is an inadequate base on which to distinguish between professions, and looks at how the professionalization strategy of nursing is advancing but at the same time is also limited by the profession itself, mainly because of its emphasis on rule-bound behaviour. The third chapter takes a theoretical context, drawing on the sociology of the professions, and explores some of the contradictions that have arisen in the search for efficiencies in an environment of cost containment. Chapter 4 considers the Fordist influences in hospital management, and contrasts the situations within two different hospitals. Chapter 5 looks at issues relating to the management of professional workers, and Chapter 6 considers the extent to which the NHS can be said to be moving towards postFordism. The people who will benefit most from this book are students from the various disciplines on which it touches, the sociology of work and of the professions and those in applied health service studies including professional education.

There is much that we found useful in this book. Our main disappointment is that although the authors claim to give much emphasis to gender issues, and allude to gender from time to time throughout the book, we do not feel they adequately address important structural as well as psycho-social issues. They do not, in our view, adequately develop their analysis of the social construction of occupations along gender lines, nor of the hierarchical nature of both professions and the closure within professions of posts which carry real power. It is a striking feature of their empirical data that nursing is trying to get more status and power for itself by assuming a 'male' view of work. It is reclaiming power by taking on technical tasks instead of trying to get higher status in society for caring work. It also seems inevitable that the 'lower status' tasks 
including caring will be passed on to the care assistants, an 'underclass' on the wards who will be predominantly female with a higher proportion of black people. These issues are not fully addressed in the book. (Another issue which is therefore not addressed is that of middle-class women exploiting lower-class women.)

We agree with much of the authors' analysis of the coexistence of both Fordism and post-Fordism, and the conflict and confusion this creates for workers in the NHS. However, as more recent academic literature on organizations and management point out, conflicting tendencies, contradictions and paradox are 'normal' aspects of work organizations operating in an uncertain and complex world. And workers such as the doctors and managers in this study engage in defence routines and overt as well as covert politicking.

Finally, Walby et al. recognize that the cause of the wider structural change has been political. However, we think that this point could have been taken further. What has happened in recent years in the NHS is that politicians have devolved political decisions on to people employed within the health service. In a way it seems that politicians have 'shirked' their responsibilities for the changes they have instigated, and managers, doctors and nurses find themselves accountable for these wider political decisions and become easy scapegoats when things go wrong.

Marie-Claude Foster and Susan F. Murray 